\title{
Sacred Hoop Dreams: Basketball in the Work of Sherman Alexie
}

\author{
David S. Goldstein \\ University of Washington, Bothell
}

The game of basketball serves as a fitting metaphor for the conflicts and tensions of life. It involves both cooperation and competition, selflessness and ego. In the hands of a gifted writer like Sherman Alexie, those paradoxes become even deeper and more revealing. In his short story collections, The Lone Ranger and Tonto Fistfight in Heaven and The Toughest Indian in the World, his debut novel, Reservation Blues, and his recent young adult novel, The Absolutely True Diary of a Part-Time Indian, Alexie uses basketball to explore the ironies of American Indian reservation life and the tensions between traditional lifeways and contemporary social realities. So central is basketball to the Lone Ranger and Tonto short story collection, in fact, that the paperback edition's cover depicts a salmon - the Coeur d'Alene Indians are fishermen—flying over a basketball hoop.

Communal experience typically trumps individualism in American Indian value systems, experience that often manifests itself in leisure activities of North American Indians. Although most contemporary anthropologists wisely hesitate to generalize across hundreds of American Indian societies, they do report, as 


\section{Ethnic Studies Review Volume 32.1}

do American Indian scholars and storytellers, that the sacredness of life, the balance or harmony of relationships among humans and between humans and nature, and the cultural centrality of stories characterize most Indian groups. Certainly the writings of American Indian authors like Michael Dorris, M. Scott Momaday, Leslie Marmon Silko, and Louise Erdrich return often to such themes.

It is no wonder, then, that such values inform the leisure pursuits of American Indians, at least as interpreted by its artists like Alexie. Indeed, as Daniel McDonald and Leo McAvoy point out, the connection between leisure and other aspects of life are less starkly drawn in most American Indian societies than they are in Euro-American society. This interrelationship between life and leisure manifests itself quite thoroughly in Alexie's work, especially in his treatment of basketball. As just one example, a character named Simon in a story titled, "The First Annual All-Indian Horseshoe Pitch and Barbecue," jokes that basketball should be their new religion, noting, "A ball bouncing on hardwood sounds like a drum" (147). And in "Saint Junior," a story in The Toughest Indian in the World, the narrator tells us that the protagonist had participated in "many of the general American Indian ceremonies like powwows and basketball tournaments" (183), unironically implying equivalence between the two.

So important is basketball to Alexie's literary cosmos that the narrative voice in his poem, titled, "Why We Play Basketball," apparently speaking on behalf of all Indians, or at least Alexie's own Spokanes, dramatically insists,

It is just a game

we are told by those

who cannot play it

unless it is play.

For us, it is war .... (711)

Although equating sports with war is hardly a new literary gesture, Alexie gives the impression- that the connection for him is literal, not figurative.

Alexie's poem also suggests that basketball helps Indians make 
sense of their daily lives and their place in the larger world:

In basketball, we

find enough reasons

to believe in God,

or something smaller

than God .... (711)

The narrative voice states that Indians play basketball because "we want to / separate love from / hate, because we know / how to keep score" (712) — the game, like a story, reflects life back to us, giving it meaning. Finally, the voice draws a parallel between the ball and the tribe itself: "These hands hold the ball. / These hands hold the tribe" (712). In one short poem, Alexie thus uses basketball to evoke epic themes of war, God, and peoplehood, themes that also run through his longer works.

In The Absolutely True Diary of a Part-Time Indian, his National Book Award-winning novel for young adults, Alexie's protagonist, an adolescent Indian nicknamed Junior, literally and figuratively leaves his reservation to attend high school in the nearby white town. An outsider in every way, Junior earns a place on the white high school's basketball team, and the court becomes the stage upon which he struggles between his loyalty to his people and his reservation on the one hand and, on the other, his commitment to escape the cycle of poverty and hopelessness on the reservation.

Recalling the reservation's eighth-grade football team's 45 to 0 loss to their opponents from the white town, Junior says, "Of course, losing isn't exactly fun. Nobody wants to be a loser" (49). To Junior, losing a game signifies losing at life. He speaks of loss again later after reading Euripides's play, Medea, in which the title character asks, "What greater grief than the loss of one's native land?" Junior responds,

I read that and thought, "Well, of course, man.

We Indians have LOST EVERYTHING.

... We only know how to lose and be lost." (173)

But when Junior's high school basketball team routs the reservation team, and Junior holds his former best friend, the 


\section{Ethnic Studies Review Volume 32.1}

reservation team's top shooter, to four points, Junior realizes his victory means his friend's, and his tribe's, defeat. As a sign of Junior's coming of age, he also understands that he can live in multiple worlds, from the tribe of Spokane Indians to the "tribe of teenage boys," the "tribe of poverty," and, "the tribe of basketball players" (217). Fittingly, the novel ends with a rapprochement between Junior and his best friend, whereupon they play one-on-one "until the moon was huge and golden and perfect in the dark sky" (229). "We didn't keep score," Junior adds (229). In Junior's maturing mind, basketball no longer serves only to distinguish the winners from the losers. In his more complex cosmology, Junior's concept of basketball transcends the binary and becomes a metaphor for a capacious, complex, and joyful world.

In The Absolutely True Diary, as in all of his works, Alexie aggressively reminds us that American Indians live their lives in the contemporary world. His unflinching depiction of reservation poverty, based, as he has said, on his own memories, makes basketball a natural form of recreation on the reservation. Basketball is popular on reservations for the same reason it is popular in other disadvantaged pockets of America: it costs virtually nothing to play. In The Toughest Indian in the World, the narrator of the story "Saint Junior" - perhaps the same Junior in The Absolutely True Diary - says that a character named Roman Gabriel Fury "knew that basketball was the most democratic sport. All you needed to play was something that resembled a ball and something else that approximated the shape of a basket" (156). However, Alexie resists the essentializing and reductionist notion that Indian behavior and beliefs can be so neatly generalized. His use of basketball as metaphor is complicated and nuanced.

Some of the stories suggest that the basketball players on the Spokane Indian Reservation in eastern Washington-where Alexie himself grew up-value service to their team above personal achievement or victory over an opponent. Junior Polatkin, a character who recurs in several stories in The Lone Ranger and Tonto Fistfight in Heaven, says that their reservation basketball team-ironically called the Wellpinit Redskins_had good players but rarely won: "We always had two or three of the best players 


\section{Goldstein-Sacred Hoop Dreams}

in the league, but winning wasn't always as important as getting drunk after the game for some and for [sic] going to the winter powwows for others," he says (206).

Other stories, however, feature players who are reservation legends for their individual magic on the court. In "The Only Traffic Signal on the Reservation Doesn't Flash Red Anymore," for example, the narrator, Victor, says:

There's a definite history of reservation heroes who never finish high school, who never finish basketball seasons. Hell, there's been one or two guys who played just a few minutes of one game, just enough to show what they could have been. And there's the famous case of Silas Sirius, who made one move and scored one basket in his entire basketball career. People still talk about it.

\section{"Hey," I asked Adrian. "Remember Silas Sirius?"}

\section{"Hell," Adrian said. "Do I remember? I was there when} he grabbed that defensive rebound, took a step, and flew the length of the court, did a full spin in midair, and then dunked that fucking ball. And I don't mean it looked like he flew, or it was so beautiful it was almost like he flew. I mean, he flew, period." (47)

Laughing, Victor states, "A reservation hero is a hero forever" (48). Yet the characters sadly observe that the hero, like hope on the reservation, rarely transcends bleak reality: Sirius died of diabetes before making his comeback. Having already complicated the simplistic notion that individual heroics have no place in American Indian life, Alexie then twists the knife, confronting the complementary realities of both legend and material life. Victor asks, "But what happens when our heroes don't even know how to pay their bills?" (49).

Alexie uses basketball to conjure poignancy in other stories, as well. In "Indian Education," written in the form of brief diary entries from first through twelfth grade, the narrator, Junior, writes of the first time he picked up a basketball in fifth grade saying that "it 


\section{Ethnic Studies Review Volume 32.1}

felt good, that ball in my hands, all those possibilities and angles" (175). Later, though, in eleventh grade, he writes this entry:

Last night I missed two free throws which would have won the game against the best team in the state. The farm town high school I play for is nicknamed the "Indians," and I'm probably the only actual Indian ever to play for a team with such a mascot.

This morning I pick up the sports page and read the headline: INDIANS LOSE AGAIN.

Go ahead and tell me none of this is supposed to hurt me very much.

With a single newspaper headline with a double meaningIndians losing once more in the game of hoops and in the game of life-Alexie pushes basketball to mean far more.

In Reservation Blues, which stars Thomas Builds-the-Fire from The Lone Ranger and Tonto Fistfight in Heaven, Alexie uses another basketball allegory to help provide insights into himself, his father, and the larger Spokane culture. With his father asleep, drunk, on the kitchen table, Thomas begins to tell his guests, sisters named Chess and Checkers, about his father's fall from greatness. He tells them that his father, the Washington State High School Basketball Player of the Year in 1956, was so good that he was a reservation hero, of whom the tribe began to expect miracles. Thomas says, "Sometimes they'll stop a reservation hero in the middle of the street, look into his eyes, and ask him to change a can of sardines into a river of salmon" (97). Once his father started drinking, though, he did not stop, continues Thomas.

Soon, Thomas launches what becomes a continual story of his father, Samuel Builds-the-Fire, and his fellow Spokane, Lester FallsApart, who end up challenging the brutal tribal police to a hoops game after a confrontation. The court becomes a battleground. The tale, which readers encounter in installments throughout the novel, becomes not only a method of characterizing Samuel as well as Thomas through his memories of his broken father, but 
also a thematic thread running through the plot like a point guard weaving through defenders to the key. As the face of authority on the reservation, the tribal police are depicted as violent traitors to their fellow Indians, and the skirmish quickly takes on epic meaning.

The narrative returns episodically to the great game over the space of more than twenty pages, as Samuel and Lester first take the lead (103), then lose it to the tribal police (113), regain it (117), and again slip behind (121). Finally, down by one point, Samuel makes a legendary jump shot in a passage that recalls the theme of flying humans in Toni Morrison's Song of Solomon and other African American texts: "Samuel flew. He had dreamed of flying before. But there he was, flying for real. Flying true. ... Samuel laid the ball gently over the rim" (126). The narrator then hits the reader in the gut with the simple declaration, "Samuel missed the shot" (126). This story is no Hoosiers, in which the underdog triumphs. Ultimately, the chapter ends with Chess saying to Thomas, "You never told us who won that game between your father and the Tribal Cops."

"Who do you think?" Thomas asked. "Who you think won that game?"

The text offers no definitive answer, but it seems clear that one can expect another headline to read, "INDIANS LOSE AGAIN." Alexie leaves the gap intentionally, forcing readers to reach their own conclusions regarding the Indians' chances in the game of basketball and, by extension, in the game of life.

Again, however, Alexie thwarts simple interpretation. At the end of the novel, the Catholic priest, Father Arnold, who, despite his human faults, stands as a force for good on the reservation despite being white, leads the Catholics to a basketball championship victory over a rival church on the reservation. When an opponent hints that Father Arnold spent too much time practicing at the expense of his parish, a member of the church retorts, "[W] hat the hell do any of you know about being Catholic? You have no idea how hard it is" (293). Indeed, as the readers know, Father Arnold 


\section{Ethnic Studies Review Volume 32.1}

had had to muster enormous self-control to maintain his celibacy after Checkers begins to fall in love with him. The challenge of maintaining integrity in the face of external challenges is not, Alexie implies, the sole territory of the American Indian.

In the remarkable 1998 film, Smoke Signals, whose screenplay he wrote based on the stories in The Lone Ranger and Tonto Fistfight in Heaven, Alexie further develops the basketball metaphor. Smoke Signals focuses on two less-prominent characters in Lone Ranger, Victor Joseph and Thomas Builds-the-Fire, who embark on a road trip from the Spokane reservation to Phoenix, where Victor's estranged father, Arnold, has died. In a flashback that fleshes out a story that Arnold's girlfriend tells Victor after Victor arrives to claim his father's body, Arnold stands alone on a court outside his trailer in the desert. Looking at the ball, he begins a monologue to himself, which is worth quoting at length:

Everything in the world can fit inside this ball. God and the Devil, cowboys and Indians, husbands and wives, fathers and sons.

And how does it all fit? It's about magic, man. It's about faith. It's about holding this ball in one hand, and in the other hand, you're holding the hearts of everybody who's ever loved you.

You know, this one time, me and my son, Victor, we was playing this two-on-two basketball game against these Jesuits. Man, those Jesuits were in their white collars, in their black robes, and they was pretty damn good. By the way those priests were playing, I coulda sworn they had at least seven of the twelve apostles on their side. I mean, every time I tried to shoot the ball, this storm of locusts would come flying in and blind me. I was shooting in the dark, I tell you! But my boy, Victor, he was magical. He couldn't miss. Those Jesuits didn't have a prayer of stopping him fair and square. But Victor, he was only about twelve years old and he was kinda small, so those Jesuits were beating up on him pretty good. They were beating up 
on him and chanting at him like Victor was possessed or something. And maybe Victor was possessed, by the ghost of Jim Thorpe or something, because he had this look in his eyes that was scary. It was mean. "Come on, Victor," I shouted. "We're playing the Son and the Father here, but these two are going to need the Holy Ghost to stop us!" I mean, the score was tied up and the next basket wins, you know? So, the Jesuits had the ball, and this big redheaded Jesuit drove in and knocked my boy over, you know? Just bloodied Victor's nose all up. All that Jesuit could say was "Forgive me." Can you believe that? But my boy, Victor, he was tough. He just wiped that blood on his sleeve, picked up the ball, and took it to the hoop. He flew, man, he flew, right over that Jesuit. Twelve years old and he was like some kind of indigenous angel. Except maybe his wings were made from TV dinner trays! Ha! But my boy, Victor, he was the man that day. He took that shot and he won that game. It was the Indians versus the Christians that day and for at least one day, the Indians won." (86-87)

But when the story flashes forward to the present, Victor tells Arnold's girlfriend, Suzy Song, that he had missed that shot. His father had lied to make his son look better. So, with Arnold's tale, the audience first believes that the Indians won that symbolic victory that day, only to be disillusioned. But because Alexie layers cynicism with hope, we recognize, as does Victor himself, that Arnold loved him in his own way. He was proud enough of his son to lie about his son's failure that day.

As Victor struggles to reconcile his desire to be loved by his father with his resentment of his father's abandonment of the family, he at first refuses to enter his father's trailer to sort through the belongings. "There's nothing in there for me," he says (93). But Suzy makes him a bet: "Hey, how about this? If I make a basket, then you have to go inside. Deal?" Victor takes the bet, and the cinematographer, Brian Capener, captures in slow motion Suzy's beautiful, graceful shot, the ball floating through the night sky like a sun (a simile, in fact, that Alexie uses in Lone Ranger). She makes the shot, and Victor, after first trying to renege, enters the trailer, 


\section{Ethnic Studies Review Volume 32.1}

symbolically entering his father's world, a first step toward his psychic reconciliation.

Suzy then tells him his father's greatest secret, the one that drove him from the reservation: His father had accidentally started the fire that killed his friend Thomas's parents. By coming to terms with his father and the truth of his past, Victor reconnects with his own roots, growing closer to the memory of his father and to his irritating friend, Thomas Builds-the-Fire, whose parents Arnold had accidentally killed so many years earlier.

An interestingly parallel scene takes place in "Saint Junior," a story in the The Toughest Indian in the World volume. Although a mediocre, semi-professional basketball career haunts the protagonist, Roman Gabriel Fury, the story tenderly depicts his love for his wife, Grace Atwater. At the end of the story, Roman tries to melt the snow on the half-court outside their reservation home by lighting kerosene he had poured on the snow (a scene that recurs in his poem, "Why We Play Basketball"). When Grace comes out to see him, she reveals that she is wearing nothing beneath her coat.

"You make the next shot and you can have all of this," she said.

"What if I miss?" he asked.

She closed the coat tightly around her body.

"Then," she said, "you'll have to dream about me all day."

"Hey," he said, his throat suddenly dry, his stomach suddenly nervous. "We've got to be to work in fifteen minutes."

"Hey," she said. "It's never taken you that long before. I figure we can do it twice and you'll still be early."

Grace and Roman smiled.

"This is a good life," she said. 


\section{Goldstein-Sacred Hoop Dreams}

He stared at her, at the basket, at the ball in his hands. Then he lifted the ball over his head, the leather softly brushing against his fingers, and pushed it toward the rim.

The ball floated through the air, then, magically, it caught fire. The ball burned as it floated through the air.

Roman and Grace watched it burn and were not surprised.

Then the burning ball hit the backboard, rolled around the rim, and fell through.

Grace stepped toward her husband. Still burning, the ball rolled to a stop on the frozen ground. Roman stepped toward his wife. Ceremony. (187-88).

The ball, a spot of warmth in the cold, white snow: the basketball represents hope and joy as much as it suggests a world of disappointment and arbitrary chance.

And here we see it all come together: the connection to the past with a foot in the present, the blurry dichotomy of the real and the imaged, fate and self-determination, the awake and the dreaming, harmony with nature and with others, self-identity balanced with membership in a family and a tribe-all brought together through the rotating planet of a basketball, and, significantly, through telling stories about basketball. Alexie knows, as irrepressible Thomas Builds-the-Fire knows, stories are everything.

\section{Bibliography}

Alexie, Sherman. The Absolutely True Diary of a Part-Time Indian. New York: Little, Brown, 2007.

---. The Lone Ranger and Tonto Fistfight in Heaven. 1993. New York: HarperPerennial, 1994.

---. Reservation Blues. New York: Atlantic Monthly, 1995. 
---. The Toughest Indian in the World. New York: Grove, 2000.

---. "Why We Play Basketball." College English 58.6 (Oct. 1996): 709-12.

McDonald, Daniel, and Leo McAvoy. "Native Americans and Leisure: State of the Research and Future Directions." Journal of Leisure Research 29.2 (1997): 145-66.

Morrison, Toni. Song of Solomon. 1977. New York: Plume, 1978. 